\title{
10. Tackling economic inequality
}

\author{
Andrew Bradstock
}

\section{Introduction}

'Recession takes its toll on wealth of Kiwi rich list' ran a headline in the Business and Money section of the Otago Daily Times in July 2009 (Hartley 2009). It was a story unlikely to have pulled at readers' heartstrings, yet it listed how, according to figures compiled by the National Business Review, in the preceding 12 months \$5.7 billion had been lost from the combined wealth of the 155 entrants on the rich list, a fall from $\$ 44.4$ billion in 2008 to $\$ 38.7$ billion for 2009. No one, it seems, managed to escape the ravages of the recession, not even New Zealand's richest person, Graeme Hart, who lost a cool \$500 million in that 12-month period (though he remained well clear of the pack with assets in the region of $\$ 5.5$ billion).

My purpose here is not to debate the rights and wrongs of individuals or families owning vast amounts of money per se - although writing from a theological perspective one could certainly mount an interesting critique using images of camels and eyes of needles, sycamore trees, and perhaps even Abraham's bosom. And no doubt this would be a timely challenge - as if the recession had not provided that already - not to lay up treasures on earth. Rather, I want to explore the implications for a society - in particular, New Zealand society - of such extreme levels of wealth existing alongside very serious levels of poverty. Does the rich-poor gap in New Zealand matter? Should it be a matter of concern if it continues to widen? What consequences does it have for the health and well-being of New Zealand communities? Ought Kiwis to look to their government, not just to reduce poverty, but to tackle inequality? Or is this simply to engage in the politics of envy, to show righteous indignation without achieving anything worthwhile?

After some preliminary ground-clearing I want to look at this question of inequality, first from a theological perspective - because the Bible has much of interest and relevance to say on the topic - and then at some recent research in the field of public health into the social implications of 'unequal' societies. Finally, I want to argue that, in any debate about the economy, the question of inequality should be central. But first, I need to back up my claim that New Zealand has an issue with 'inequality' that should concern us. 
Public Policy: Why ethics matters

\section{Identifying the issue}

In their study published in 2009, The Spirit Level: Why more equal societies almost always do better, UK academics Richard Wilkinson and Kate Pickett produce data showing, for each of 23 developed countries, how much richer the richest 20 per cent of the population is than the poorest 20 per cent. Way out ahead is Singapore, whose top 20 per cent of citizens are nearly 10 times richer than its poorest 20 per cent, with the United States second with a figure of just over eight times. But New Zealand is tucked in there in sixth place, just behind Australia, the United Kingdom, and Portugal, with a figure of just under seven (Wilkinson and Pickett 2009, p. 17). At the other end are Japan and the four Scandinavian countries with figures around the 'four' mark. Therefore, New Zealand is among the most unequal developed countries in the world - a fact confirmed by a United Nations Development Programme report published in October 2009, the first since former New Zealand prime minister, Helen Clark, was appointed administrator (UNDP 2009). Recent data from the government also confirms New Zealand's record in terms of inequality. The Social Report for 2008 published by the Ministry of Social Development, for example, notes that New Zealand has a score of 34 on the Gini coefficient, ranking it 23rd equal (with the United Kingdom) among the 30 OECD countries (MSD 2008, p. 61). (Again, we might note that Denmark and Sweden have the lowest inequality, with scores of 23.) In 2007, Statistics New Zealand noted that the top 10 per cent of wealthy individuals own 51.8 per cent of New Zealand's total net worth while the bottom 50 per cent own 5.2 per cent (Cheung 2007, pp. 7-8).

Inequality in New Zealand rose most sharply between 1982 and 1998 when the mean household equivalent disposable income for the lowest group decile decreased 17 per cent, and rose for the top income group 36 per cent (Povey 2002, p. 22). This was a period when neoliberal market policies were initiated in New Zealand and when the move to greater inequality was seen by some 'as a badge of distinction' (Gould 2008, p. 36). It was a time when the minister of finance of the day could welcome a report describing how the bottom 80 per cent of income earners had suffered a reduction in income, and the top 5 per cent an increase, as proof that his economic reforms were rewarding those who had worked to up-skill themselves and contribute to the economy (Duncan 2007, pp. 259-60)! In 2009, the median income for wage and salary earners in New Zealand was around $\$ 35,000$ per year, with the average salary of its 44 top chief executives somewhere above $\$ 1$ million (which is not high by global standards, although in 2005 it rose 23 per cent while average wages rose 3.1 per cent, which is below the inflation rate). There is even more 'inequality' when income for Māori and Pacific peoples is considered: the average weekly income for Māori is around \$200 less than that of European/Pākehā, with Pacific people a further $\$ 50$ lower. 
Let me define precisely the problem I propose to address, because there are many 'types' of inequality and discussions in this area often get bogged down in arguments over definitions. I want to argue two distinct but not unrelated points. First, that the Judaeo-Christian principle that all people are of equal value, because they are created in the divine image, places a responsibility on communities with respect to their social and economic arrangements specifically, to ensure that none of their members are unable to meet their basic needs in terms of food, shelter, and security. And, second, that there are sound sociological as well as theological reasons for governments consciously to pursue policies aimed, not simply at relieving poverty, but at narrowing the differential between 'rich' and 'poor' in society.

Let me briefly defend theology's 'right' to engage with 'economic' issues, because it might seem an unusual conversation partner at first glance. First, there is the obvious point that people of faith represent a significant minority in society who, in any democracy, would expect to have their views heard along with everybody else. But more than this, the separation of theology and economics is relatively recent, dating, as R. H. Tawney notes, only from the development of capitalism in the 18th and 19th centuries. Until then 'economic thought had been understood as part of a hierarchy of values embracing all human interests and activities, of which the apex was religion' (Gorringe 1994, pp. 31-2).

Theology can bring us 'back to basics', reminding us of the roots of the case for equality and of the capacity of markets both to enhance and destroy 'community'. Theology can also challenge widespread assumptions - for example, that economic science is the 'disinterested pursuit of truth for truth's sake', when in fact it utilises just one account of what it means to be human - homo economicus - which holds precisely that a person's life does consist in the abundance of things they possess! As the 2009 Reith Lecturer, Michael Sandel, rightly says, how priorities are allocated for spending on health, education, defence, and so on is a moral as well as an economic matter (Sandel 2009). Markets are about values, and theology has something to say about those. Importantly, markets are about relationships, and theology has even more to say about those - as it does about some of the terms economics has borrowed from it such as 'credit' and 'trust'. And it is important to remember that Adam Smith, with whom the free market will ever be associated, was first and foremost a moralist, even if his The Theory of Moral Sentiments (1759) is less well known today than his The Wealth of Nations (1776). In his much acclaimed recent book The Ascent of Money, Niall Ferguson suggests that 'financial markets are like the mirror of mankind, revealing every hour of every working day the way we value ourselves and the resources of the world around us' (Ferguson, 2008, p. 358). 
So what contribution might theology make to economic discourse? What can it usefully offer to a debate on economic equality? Let us first survey the Hebrew Scriptures, the books we usually call the Old Testament. ${ }^{1}$

\section{A theological case for equality}

A core theme in the Creation narratives in the book of Genesis is that people are endowed with an equality of worth and status by virtue of their being created by God. While all are subject to differences in terms of gender, ethnicity, size, or physical or intellectual ability - to be 'equal' is not to be the 'same', and we are to celebrate our differences - all have an inherent equality through creation. We are all 'a little lower than the angels' as the psalmist puts it, and bear to an equal extent the 'image of God'.

For the writers of Genesis, because all people are made in the image of God, all should reflect that by enjoying the basic gifts God bestows upon Creation. The land and its fruits are freely given to all to enjoy, with none being apportioned a greater share than any other. The old medieval saw, 'When Adam delved and Eve span, Who was then the gentleman?' sums it up perfectly (if we overlook the gender stereotyping). That inequality has been such a feature of human existence since the Creation is a consequence of human action, of the Fall, not the outworking of a divine plan: as the 4th century writer Pelagius rather tellingly put it, reflecting on 'natural' gifts we enjoy such as the sun and the air (in Bradstock and Rowland 2002, p. 18):

we possess equally with others all the things which are not under our control but which we receive by God's dispensation, and on unjust and unequal terms only the things which are entrusted and subjected to our own rule ...

Affirmations of our inherent equality under God appear throughout the Hebrew Scriptures. While disparities of wealth and status are evident and acknowledged - the riches of certain patriarchs and kings are described uncritically or taken as a sign of divine blessing, and the existence of slaves is accepted - a concern that none should be denied their basic needs is constant. For the biblical writers, the fundamental equality of all people before God means that all must have their basic needs met, and many reserve their sharpest invective for rulers who act unjustly in this respect.

1 I limit myself in this paper to the Judaeo-Christian scriptures, but there are numerous relevant and stimulating insights into economic matters in Islamic teaching, which I have drawn on in other commentaries on the global economic crisis. 
God is perceived to be against systems that institutionalise the exploitation of the poor. This is most clearly seen with respect to the distribution of that most basic commodity, land. In Numbers chapter 26, when Moses divides the land among the tribes in proportion to their size, he does it by lot to prevent the most powerful securing for themselves the best. The Jubilee laws stipulated that land was never to be sold in perpetuity, that those who benefited from the poverty of others by buying up their land should not retain it permanently. While these laws did not envisage a fully 'egalitarian' society, they did aim for a degree of equalisation through workable redistributive mechanisms. The prophets Isaiah, Micah, and Zechariah all envisage a time when everyone will enjoy the security that comes from having their own access to the necessities of life. Observing the Sabbath also had an equalising dimension, because in so far as it obliged rich and poor alike to abstain temporarily from work it provided a break in those patterns of relationships that sustain inequality.

Underpinning the concern that all should have equal access to land is the importance of community: in biblical terms, it is fundamental that no one is denied membership of their community on account of their economic circumstances. Where material aid is given it is to enable the impoverished person to live once again alongside their helpers. Community is predicated on an assumption that every person can maintain their own well-being: this seems to be the point of the prophets' depiction of 'all sitting beneath their own vine'. Where even one person becomes dependent on others the community is deficient, hence the importance of all having access to the land.

The New Testament also suggests that community exists only when all members are held to be equal. In his first letter to the Corinthians, chapter 12, Paul uses the metaphor of the body to describe the relationship between the followers of Christ, stressing that all limbs and organs are of equal value and equally vital to making the body function. As people join the fellowship of Christ, so their social status or standing diminishes in importance. True fellowship cannot exist where some members are held in higher esteem than others.

A striking example of equality among the early Christians appears in the Acts of the Apostles chapter 4, where the Jerusalem church preferred sharing goods to private ownership. Those who owned lands or houses sold them and the apostles distributed the proceeds to those in need. Again, the requirement that basic needs be met seems to have been fulfilled in that 'there was not a needy person among them' - an echo of the outcome when the people of Israel observed the Jubilee. Equality between churches was also important for Paul, as his call to the Corinthians to share their goods with a poorer fellowship suggests (II Corinthians chapter 8). This passage has echoes of the provision of manna in the wilderness, where 'those who gathered much had nothing over, and those who gathered little had no lack' (Exodus chapter 16). 
The Mass or Communion also speaks of equality, anticipating powerfully the heavenly banquet when none shall be distinguishable by rank or status. It remembers the One who taught that, while in society people pull rank on one another, 'it shall not be so among you' (Mark chapter 10 verse 43). 'The last will be first and the first will be last' (Matthew chapter 20 verse 16).

At the beginning of Luke's account (chapter 4 verses 18, 19) Jesus affirms his call to proclaim the year of the Jubilee, and a leitmotif of his teaching was that, in the kingdom, the poor and humble are raised up and the rich and important brought down. Mary prefigured her son's mission by speaking of God filling the hungry with good things and sending the rich away empty, and Jesus challenged people to sell their possessions and give to the poor. Entry into the kingdom will not be possible without the abandonment of wealth - presumably, because there the categories of 'rich' and 'poor' do not exist.

\section{Social consequences of inequality}

In so far as the biblical writers are unequivocal in affirming (a) the fundamental equality of all people before God, (b) the social responsibilities placed on those with wealth, and (c) the duty of communities to ensure all members enjoy the basic needs of life, they speak a challenging word to Western societies. Confronting a culture characterised by a spirit of 'autonomy' and lack of communitarian connectedness - one that 'understands the market as a place for self-advancement at the expense of others, who are perceived either as rivals and competitors or as usable commodities' (Brueggemann, 2009, p. 5) - the Bible offers a radically different model. According to the Bible's writers, the whole point of economic arrangements is to build up and sustain communities. Therefore, they will incorporate measures to protect the interests of the most vulnerable and marginalised and ensure they can participate as fully in the community as everybody else. And while it would be a mistake to seek to 'apply' to our own context biblical economic models, there is much value in reflecting on how Scripture can help to foster the well-being of our own communities today, and discerning how its principles can most helpfully contribute to debates in the public square about the common good.

This is a singularly apposite time to be doing this, faced as we are with a global economic crisis crying out for fresh solutions. As we survey the fall-out from the present recession, and peer into an uncertain future, I believe our energies must be directed toward discerning, not so much how we can all get richer again, but how to improve the psychological and social well-being of our society as a whole. As surveys are continually showing, for those of us in the developed world who have reached the point where our worries for the future 
no longer centre around finding enough food, water, or shelter, becoming richer increases our quality of life hardly at all. Indeed, it can be demonstrated that as affluent societies have grown richer, so there have been long-term rises in rates of anxiety, depression, and other social problems. Hence, I believe it is time to expand the debate about how we achieve economic growth by seeking a shared vision of a better society.

For while New Zealand - like every other country in the developed world has seen a significant increase in gross domestic product in recent decades, this has not led to a concomitant decrease in social problems. The media bring news every day of our 'need' for more prisons; of alarming rises in obesity, including among children; of growing alcohol consumption among the young, with a resultant rise in anti-social behaviour; of growing depression and other psychiatric problems; and of how we are rapidly bringing about the demise of our own and other species by our rapacious and unsustainable lifestyle. It is difficult to avoid the conclusion that New Zealand society, like many others in the Western world, is becoming increasingly dysfunctional, and that, rather than seeking out and addressing the root causes, we do little more than attempt to treat the symptoms. Surveys show that as citizens, we are more concerned about the quality of our lives than simply our wealth. However, politicians across almost all the main parties seem reluctant to take any new or imaginative steps (though it will be interesting to see if any will follow the lead of the French president, Nicolas Sarkozy, who said in September 2009 that his country will now include happiness and well-being in its measurement of economic progress) (Aldric 2009).

Therefore, I want to argue that (a) we need a debate now about how we renew our society and (b) central to this debate must be the thorny issue of economic inequality. I argue this, not just on the basis of the theological case I made earlier, but because we now have to face the extremely convincing claim, drawing on some 30 years of painstaking research, that one of the key factors - if not the key factor - behind dysfunctional societies is their level of economic inequality. In study after study it has been shown that countries with high levels of inequality - like New Zealand - will imprison a larger proportion of their population, have lower literacy scores, have more obesity, have more teenage pregnancies, have worse mental health, and have shorter average life-spans than those countries with much lower levels of income inequality. Richard Wilkinson and Kate Pickett have brought this research together in their book The Spirit Level (2009). They spell out their findings with a series of graphs disturbingly similar in appearance, and state that (2009, p. 181):

across whole populations, rates of mental illness are five times higher in the most unequal compared to the least unequal societies. Similarly in 
more unequal societies people are five times as likely to be imprisoned, six times as likely to be clinically obese, and murder rates may be many times higher.

And note that Wilkinson and Pickett say, 'across whole populations': it is not simply that in more equal societies there will be fewer poor people, that equality helps only those at the bottom: the effects of inequality affect everybody. ${ }^{2}$

Inequality, then, has a significant effect on all our lifestyles in wealthier countries. We often talk about being a consumer-oriented society, about how we buy lots of things yet end up being less happy: and scientific surveys into 'happiness' show that this is exactly the case. But the reason we buy things is less because we need them than that growing inequality has put pressure on us to maintain standards relative to others. Contentment has less to do with actual wealth than relative wealth, a factor that explains why we continue to pursue economic growth despite its apparent lack of benefits. In this connection it is interesting to note that spending on advertising also varies with inequality - in more unequal countries a larger proportion of gross domestic product is spent on advertising, with the United States and New Zealand spending twice as much as Norway and Denmark (Wilkinson and Pickett, 2009, p. 223).

Reducing inequality is also vital to our effort to help the environment. Instead of responding to constant pressure to devour ever more of the earth's resources, we need to focus on how to live sustainably - which will involve cutting back on our consumption and taking more seriously radical new ideas such as 'biomimicry' that explore technological changes to enable our resource use to replenish rather than destroy the ecosystem. ${ }^{3}$ We might note, however, that doing this will not lead to any reduction in our real quality of life as measured in terms of health, happiness, and community life. Another interesting finding by Wilkinson and Pickett is that, because more equal countries manifest a greater sense of community spirit, their approach to environmental issues is more enlightened - so Japan and Sweden recycle a significantly larger proportion of their waste than do the United States and United Kingdom (Wilkinson and Pickett, 2009, p. 228).

\section{Can we reduce inequality?}

I have raised the possibility that we might want to break out of the spiral of consumption in which we find ourselves trapped, and rediscover ways in

\footnotetext{
2 For a useful, critical discussion of this point, see Runciman (2009).

3 For more on this see, for example, the Biomimicry website (www.biomimicry.net) and the website of Professor Dr Michael Braungart (www.braungart.com).
} 
which the economy can benefit the whole of society. And I have argued that central to this task must be a commitment to reverse the trend that has seen economic inequality increase in the past few decades. At the risk of sounding like a religious or political fundamentalist who thinks there is one solution for all ills, I have argued that a mass of evidence suggests that across a wide range of social indices - from mental health to educational performance to rates of imprisonment to life expectancy - the more unequal a society, the less well it performs. But can anything be done about economic inequality, and if so, what?

The key to the kind of change I am advocating is political will, and there are few signs of that at present, whether in New Zealand or most other developed countries. Political will can, of course, be influenced by changes in the mood of voters, but given that popular concern in New Zealand about the level of inequality has decreased in the last 20 years, despite inequality itself having increased significantly during that period, signs of a change of thinking at governmental level are not immediately hopeful. ${ }^{4}$ This, however, is in contrast to the situation in some other developed Western nations. Surveys in the United Kingdom over the last 20 years, for example, have shown that the proportion of people who think that income differences are too big is around 75 per cent to 80 per cent. Perhaps even more surprising is the 2005 Maxwell Poll on Civic Engagement in the United States that reported that over 80 per cent of the population thought that the extent of inequality was a problem, with 60 per cent believing the government should try to reduce it - figures that reinforced the findings of various Gallup polls between 1984 and 2003. These figures are even more remarkable given that most respondents underestimated how big the income differences were in their society.

In one sense there is a 'spiritual dimension' to this process, in that the kind of change necessary to make any significant difference in terms of reducing inequality would resemble that implied in the theological category of 'metanoia'. Metanoia speaks of a fundamental transformation of our vision of the world and ourselves, a radical change of mind or re-orientation linked to sorrow for the past. However, experiments have shown that we have a natural propensity, when confronted by limited resources, to share rather than seek to benefit at others' expense (Wilkinson and Pickett, 2009, pp. 199-200). As Marshall Sahlins pointed out in his study Stone Age Economics, for over 90 per cent of our time on this planet we lived, almost exclusively, in highly egalitarian societies where 'social and economic life was based on systems of gift exchange, food sharing, and on a very high degree of equality' and where 'forms of exchange involving

4 Data produced by the International Social Survey Programme in 2009 showed that 60 per cent of the population considered income differences in New Zealand were too large compared with 70 per cent in 1992 (Staff Writers 2010). 
direct expressions of self-interest, such as buying and selling or barter, were usually regarded as socially unacceptable and outlawed' (cited in Wilkinson and Pickett, 2009, pp. 198-9).

Therefore, what measures might be adopted to reduce inequality in our society? It could be argued that it is not the business of 'theology' to offer concrete economic policies. However, it is rather a cop-out simply to critique a situation without offering alternatives, so let me try to outline possible issues to engage with if the business of tackling economic inequality is to be addressed. And note that these are simply 'issues' not solutions: my main concern is to promote debate and in so doing offer one or two pointers to what might be on the agenda.

\section{A progressive role for the state}

One issue we might as well confront head-on is the role of the state. When R. H. Tawney, arguably the most influential Christian advocate of economic equality in the 20th century, considered how the principle of equality that he discerned in Scripture could be reflected in social and economic structures, he assumed that the state would play a powerful role. For Tawney, the state had a duty to operate in the public interest and to use the levers of taxation and social security to ensure that differences of wealth and income were gradually narrowed - an assumption many of his readers in the 1920s and 1930s would have shared. Indeed, another great architect of the welfare state, Archbishop William Temple, argued that the state had a duty to ensure all families had an adequate income, good housing, and access to education, and the post-war Labour government in Britain (1945-51) enjoyed widespread public support when it nationalised key utilities and centrally administered a raft of services including education, health, and housing.

Today the issue is less clear-cut. While some still see the state as pivotal in the quest for equality, and taxation as a vital lever in the project, others argue that the greater freedom given to the market since the 1980s has raised living standards across the board and made the very notion of 'inequality' seem outdated. While government control of the 'commanding heights' of the economy in the public interest may have been welcomed by a people shattered by the ravages of war, today the idea that bureaucrats and politicians know best about providing services is seen as hopelessly outdated. It is true that Tawney - and for that matter his contemporary Beveridge - did not see the state as the only agency with the power to promote equality, arguing that local authorities, individual citizens, and what we would now call the 'third sector' (voluntary bodies and community groups) also had a crucial role. Now, however, the received wisdom on both the 'left' and 'right' is that the era of the 'big state' and government 
welfare as the 'institutional expression of altruism' has long passed, replaced by concepts like 'stakeholder welfare' and an emphasis on individual responsibility and the role of the voluntary sector. Yet attractive though these ideas are - and they have much to commend them from a theological perspective - the case for pressing toward greater equality, and for this to be a consciously shared project under government direction, still seems compelling.

Take the idea, which I have argued is central for the biblical writers, that everyone should receive an income sufficient to live on - an ideal also reflected in the 1948 Universal Declaration of Human Rights. While we will heed St Paul's injunction (in II Thessalonians chapter 3 verse 10) that anyone who will not work should not eat - noting that it says will not work, not cannot work - the mark of a good society must be its commitment to see that everyone receives sufficient to enable them to meet their basic needs. (And on this point, I believe we must challenge the 'distinction' often too readily drawn between the socalled 'deserving' and 'undeserving' poor.) The question then raised is, how is 'a society' to fulfil this function unless through some centrally administered apparatus?

Unlike 'relieving poverty', the business of ensuring that every person or family has the basic necessities for survival must involve some central coordination. To argue this is not to advocate a return to the heavily bureaucratic 'command economy' models of the old Soviet bloc, nor to rule out a vital role for the voluntary or business sectors or for local authorities or other agencies. But it is to rule in a 'managing' or 'co-ordinating' role for the state, rooted in a conscious commitment to achieve basic equality. While the historical argument for a 'direct' role for the state in providing for basic needs still has force, it is possible to conceive of government maintaining a 'mixed' approach to service provision, reflecting modern, progressive attitudes to the state, within a welldefined framework for tackling inequality. One lesson of history (we might take the latter half of the 19th century as a prime example) is that, for all its merits, voluntary charitable provision cannot guarantee a standard of living adequate for the health and well-being of all, so some degree of government intervention is required if this is to be achieved. The challenge for politicians is to set the balance between direct central provision and state-supported voluntary provision.

It is worth noting that societies with the greatest equality have followed different paths to that position. For example, while Sweden does it through redistributive taxes and benefits and a large welfare state, Japan has a greater equality of market incomes, of earnings before taxes and benefits. As a proportion of national income, public social expenditure in Japan is among the lowest of the major developed countries. How might things be approached in New Zealand? 
One focus might be the minimum wage and welfare and pension levels and the methods used to set these levels. Should the merits of a living wage be considered, as well as welfare rates and pensions that take into account research into minimum income standards? Should incomes - especially those of people on the minimum wage - rise in line with average earnings (noting that an unemployed person receives less than 30 per cent of net average wages)? This would act as a brake on inequality and ensure the lowest earners do not get left even further behind. How about a return to a system of universal child support, since there is strong evidence to show this contributes to reducing inequality, is efficient (in terms of resources not being wasted by the logistics of targeting), and is unaffected by changes in the economic climate? Do people know to what they are entitled and how to get it? Can the benefit system be made more transparent - and less complex? Should we think outside the box on certain questions, for example, the value of a 'universal' approach to benefits and pensions? Are the Working for Families Tax Credits the best solution for everybody (for example, single parents)? Working for Families has been excellent in almost halving child poverty in the last seven years and leading to the first reduction in inequality for 20 years - but is it time for new initiatives focused on those with the lowest incomes?

A particular challenge New Zealand faces is that its fastest growing population groups are also those with least wealth and lowest incomes, namely Pacific peoples and, albeit to a slightly lesser extent, Māori. By 2026, approximately half of New Zealand's children will be growing up in its least wealthy households, which implies an entrenching of multigenerational poverty unless this is addressed now. And what about the other end of the scale: would caps or restrictions on upper salary levels lead to any more of the best brains in the country going offshore? Cleary, New Zealand must remain an attractive place to work and do business, but inequality is a factor to be included in that equation. Could there be measures to make housing more affordable - to make more houses 'homes' instead of investment opportunities - such as tax measures on capital gains on property and on rental property (perhaps balanced by tax incentives in other areas)? Can low-cost mortgages be made more available without fuelling speculation? Some of these ideas are deeply unpopular in political circles, of course, but it does depend how debates are framed and where they start from. Bringing all this together, how about a 'commission on inequality' to examine the costs and impacts of growing wealth inequality and identify remedies that would attract broad public support?

While we might think of measures to increase people's income, a related question is whether the extra revenue needed to ensure a decent standard of living for all should be raised through taxation - particularly taxation, at a higher level than at present, of the highest incomes. This could be one way of 
meeting the twin biblical imperatives of getting the rich to 'share' their wealth with the poor and achieving a greater level of economic equality within society. However, increasing taxation is now perceived to be deeply unpopular with voters and seldom advocated by mainstream parties. While in an opinion poll in 2008 a majority of New Zealanders said they did not want personal tax cuts at the expense of basic social services, tax is still seen largely in negative terms, as something punitive and freedom-restricting rather than serving a positive function. Therefore, is there scope for a fresh debate about the purpose of tax, involving a re-examination of its potential as a contributor to the promotion of 'social justice' and greater equality, to the well-being of the whole of society? As Wellington-based commentator Melanie Downer has argued (2008, p. 12):

this is perhaps an argument that requires more explicit development in Christian circles: that the system of redistribution in the form of welfare benefits and Working for Families subsidies in New Zealand, constitutes a contemporary parallel to the jubilee ethic. In this matter, the task of Christians is to ensure that this mechanism - aimed at restoring the poor among us to a state in which they are able to participate in economic life - operates in a life-giving and sustaining way.

Perhaps even the language is important here for, as Downer says, the Jubilee system was not strictly 'redistributive' but 'restorative' (Downer, 2008, p. 6). The government's Tax Working Group, established to help it consider the key tax policy challenges facing the country, should think radically, not least because the tax cuts implemented on 1 April 2009 actually increased the gap between the highest and lowest earners because they were proportional - and even had a negative effect for those at the lower end, as they earned more in consequence and had their family tax credit reduced accordingly.

Critics of wealth redistribution to achieve social good claim that it stifles ambition and represents a loss of freedom. However, the relatively small reduction in the range of choices open to the richest 10 per cent of the population when subjected to, say, a higher level of personal taxation, compared with the enormous increase in 'freedoms' the redistribution of that wealth would mean for the very poor, makes that argument not wholly convincing. If, in the course of building an economy aimed at serving all, the choices open to the richest few diminish slightly, the 'freedom' enjoyed by society as a whole actually increases as it becomes more cohesive and the hitherto poor and disempowered have more chance to realise their God-given potential. This was a point recognised in 2009 by a group of 44 wealthy Germans, who petitioned their government to allow them to pay a 'wealth tax' to fund economic and social programmes to aid their country's economic recovery (BBC News, 2009). 
Another creative approach to tackling inequality would be to stimulate a public debate around the values of generosity and giving. New Zealand does have a tradition of philanthropy - my post at the University of Otago is living proof of that - but it is still some way behind countries such as the United States in developing a 'giving culture', a sense of putting something back into the community. No society can legislate to make people generous, but there is value in highlighting the moral issues involved and seeking to change the culture. Encouraging (perhaps by tax breaks) wealthy individuals and institutions to be more publicly linked with poverty reduction, including through corporate social responsibility programmes, could well meet with a ready response at a time when these bodies are increasingly perceived to be 'part of the problem' on account of the high profits and bonuses attending their activities.

Another approach - one suggested by Wilkinson and Pickett (2009) - could be for the government to encourage, through tax concessions, democratic employee ownership. When combined with participative management this can enable a business to become more obviously a 'working community', while also bringing the fixing of earning differentials ultimately under democratic control. It can also involve a substantial redistribution of wealth from external shareholders to employees and a simultaneous redistribution of the income from that wealth (Wilkinson and Pickett, 2009, pp. 248-56).

\section{Conclusion}

So, does it matter that some in New Zealand earn more in a month than most 'average' workers will see in a lifetime? In one sense no, for a degree of inequality of income will always exist in society. Economic equality - what we might define as 'equalised after-tax real income' - is neither practically nor politically possible, and a society with no inequality, with a Gini coefficient of 0 , would provide no incentive to advancement. Yet where conspicuous wealth exists alongside material poverty there are grounds for concern, both about the fact of that poverty and the structures that allow such gross inequality to exist. This is at the heart of what the biblical writers argue, and much of the empirical data available today confirms the continuing relevance and applicability of their concerns.

Therefore, I argue that in New Zealand, where even without this recession (which is hitting the poorest hardest) thousands of people struggle to keep warm, pay their bills, feed themselves and their families, cope with debt and ill health, and be heard in their interactions with government agencies, action is needed to bring about a greater 'levelling' of income and ensure the basic 
needs of all are met. And this action, as well as realising a more economically just society, will reap benefits across society in terms of greater cohesion, higher levels of trust, and a better quality of life.

Much of what I have been arguing is not new. In 1993, the Social Justice Statement issued by the New Zealand churches called for 'fairness in the distribution of incomes, wealth and power in our society' (Boston, 1994, p. 16). Their calls were not heeded - but this is a different time. Can all sections of society politicians, business, trades unions, faith communities - work together to tackle inequality? I hope I have shown that this has to do, not with the "politics of envy', but with recognising that the quality of our social relations is related to the material foundations of our society, that the scale of our income differences has a powerful effect on how we relate to each other, and that we need a society that materially acknowledges that all of us are made in God's image and should live in ways that reflect that status.

We do not talk much about a 'vision' for society - politics seems much more 'managerial' these days. And while this chapter does promote a vision, it is not an impossible one, for even small decreases in inequality, such as have occurred in some developed countries, can make an important difference to quality of life across society. As Wilkinson and Pickett (2009, p. 264) say:

there is a better society to be won: a more equal society in which people are less divided by status and hierarchy ... in which we regain a sense of community, in which we overcome the threat of global warming, in which we own and control our work democratically as part of a community of colleagues, and share in the benefits of a growing nonmonetized sector of the economy.

I hope that we can begin to generate a new debate about how we achieve this 'better society'.

\section{References}

Aldrick, P. 2009. 'Nicolas Sarkozy wants "well-being" measure to replace GDP.' Daily Telegraph, 14 September. www.telegraph.co.uk/finance/ economics/6189582/Nicolas-Sarkozy-wants-well-being-measure-to-replaceGDP.html.

BBC News. 2009. 'Rich Germans demand higher taxes.' 23 October. news.bbc. co.uk/go/pr/fr/-/2/hi/europe/8321967.stm. 
Boston, J. 1994. 'Christianity in the public square: The churches and social justice.' In J. Boston and A. Cameron (eds). Voices for Justice: Church, law and state in New Zealand. Palmerston North: Dunmore.

Bradstock, A., and C. Rowland (eds). 2002. Radical Christian Writings: A reader. Oxford: Blackwell.

Brueggemann, W. 2009. 'From anxiety and greed to milk and honey.' Faith and Finance: Christians and the economic crisis - Discussion guide. Washington DC: Sojourners.

Cheung, J. 2007. Wealth Disparities in New Zealand. Wellington: Statistics New Zealand.

Downer, M. 2008. 'Wealth, ownership, and social care: Towards a consideration of jubilee in New Zealand's contemporary political context.' Stimulus 16(3): 2-15.

Duncan, G. 2007. Society and Politics: New Zealand social policy. 2nd edn. Auckland: Pearson Education.

Ferguson, N. 2008. The Ascent of Money: A financial history of the world. New York: Penguin.

Gorringe, T. J. 1994. Capital and the Kingdom: Theological ethics and economic order. Maryknoll, NY: Orbis.

Gould, B. 2008. Rescuing the New Zealand Economy: What went wrong and how we can fix it. Nelson: Craig Potton.

Hartley, S. 2009. 'Recession takes its toll on wealth of Kiwi rich list.' Otago Daily Times, 25 July, p. 25.

MSD. 2008. The Social Report: Te Pūrongo Oranga Tangata 2008. Wellington: Ministry of Social Development.

Povey, D. M. 2002. How Much is Enough? Life below the poverty line in Dunedin. Dunedin: Presbyterian Support Otago.

Runciman, D. 2009. 'How messy it all is.' [Review of The Spirit Level.] London Review of Books 31(20): 3-6.

Sandel, M. 2009. 'Markets and morals.' First 2009 Reith Lecture. www.bbc. co.uk/programmes/b00kt7sh.

Smith, A. [1759] 1790. The Theory of Moral Sentiments. 6th edn. London: A. Millar. 
Smith, A. 1776. An Inquiry into the Nature and Causes of the Wealth of Nations. 5th edn. Edited by E Cannan. 1904. London: Methuen.

Staff Writers. 2010. 'All things being equal.' The Listener 223(3651). www. listener.co.nz/issue/3651/features/15346/all_things_being_equal.html.

UNDP (United Nations Development Programme). 2009. Human Development Report 2009: Overcoming barriers - Human mobility and development. Houndmills, Basingstoke, Hampshire: Palgrave Macmillan. http://hdr.undp. org/en/reports/global/hdr2009.

Wilkinson, R., and Pickett, K. 2009. The Spirit Level: Why more equal societies almost always do better. London: Allen Lane. 